\title{
Structural Changes in the Participation of African Migrants in the Labour Force of South Africa (2001 - 2011)
}

\section{Yamkela Majikijela Gabriel Tati}

\begin{abstract}
Migration is not a recent phenomenon; it is one of the three factors that contribute to the population changes. Cross-border migration between South Africa and its neighbouring countries started in the mid $-19^{\text {th }}$ century. The aim of this paper is to explore the structural changes in the participation of African migrants in the labour force of South Africa from 2001 to 2011. Furthermore, the specific objective is to demonstrate the structural changes between the two periods in the deployment of African immigrants in terms of occupation, employment sector, income groups just to name a few. 2001 and 2011 population census are used to evaluate the extent to which the situation has changed between the two periods. As far as African migration is concerned, to capture the structural changes during the ten-year period (2001 to 2011) this study focuses on variables such as demographic and socioeconomic characteristics. To profile the structural changes in the participation of African migrants, this study makes use of the 2001 and 2011 national population census data. Furthermore, statistical packages are used to test the relationship between variables. Policy document about migration are also used to provide the legislated framework with regards to the involvement of foreign labour in the South African labour force. The geographical scope of the study is national meaning it covers all nine provinces of South Africa.
\end{abstract}

Keywords: African migration; educational status; employment status; labour force; labour migrants 


\section{Introduction}

Migration in general is a complex process and involves a number of challenges. However, despite this complex process and challenges, migrant workers have been on the rise. The number of migrant workers has been continuously increasing around the world due to income inequalities and working conditions between countries. According to International Labour Organization (2010) migrant workers contribute to economic growth and development to the country of destination through their supply of labour in the production of goods and service, and through job creation for those that are entrepreneurs and are able to create jobs.

Cross-border migration between South Africa and its neighbouring countries started in the mid-19th century when the South African diamond and gold mining industries were discovered. Africans came to South Africa as temporary contract labour migrants under bilateral agreements between the apartheid government and its neighbouring countries i.e. Lesotho, Mozambique and Malawi (Crush 2008). After the apartheid government, South Africa had comparatively strong economic and political stability as compared to its neighbouring countries. This strong economic and political stability made South Africa the leading destination for migrants from neighbouring countries and the African continent as a whole (Schachter 2009). As a consequence, South Africa experienced an increase in the number of African migrants coming into the country in search for employment opportunities and/or political freedom. Ever since South Africa gained independence and became a democratic country, the country also became a choice destination for many migrants. In other words, South Africa did not just become a destination only for African migrants who were in search for employment opportunities but the country also experienced different forms of migration and a rise in the number of migrants coming into the country for different reasons. Furthermore, the country experienced an increase in the number of illegal migrants coming from neighbouring countries. The post-apartheid government still struggles to formulate policies which reflect the country's role in a changing regional, continental, and global migration regime (Crush 2008). This is evident from the continual amendments of immigration legislations in South Africa. Migration is a global problem therefore South Africa is not the only country facing difficulties in measuring and managing migration (Bhorat, Meyer, \& Mlatsheni 2002). 
Over the years the Immigration Act 13 of 2002 became insufficient to control and manage migration because the government failed to formulate a migration policy that was appropriate to address the needs of the country and its international obligations (Crush 2008). As a result the government introduced the 2011 Immigration Act which came into force in May of 2014 in order to try and manage migration.

The following sections of the paper covers the conceptual theory which guides this study. Followed by research methods, size and distribution of African immigrants, migration patterns in the labour force of South Africa, and concluding remarks.

\section{Conceptual Framework}

Generally, migration tends to be a selective process. As a result, this paper is guided by the migration selectivity theory since migrants are not homogenous, but differ in terms of demographic attributes such as sex, age, marital status and education.

Age is one of the central attributes in any study of migration because the propensity to migrate tends to vary with age. Migrants tend to be young. Often, a young person with or without education are more likely to migrate compared to people who are advanced in age. For instance, a young person who is unemployed and with little education in their home country is likely to migrate given that there is a great chance of finding employment in the receiving country (Bustamante, Jasso, Taylor \& Legarreta 1998).

Gender is central in the migration process. Generally, migrants are predominantly males but recently females have started migrating more than they did in the past. Economic, social, political pressure and/or freedom within and between countries are some of the reasons that influence both men and women to migrate. According to Jolly and Reeves (2005) the migration process has some gender implications thus the impact of migrating for both men and women depends on many factors such as type of migration (temporary, permanent, labour, independent or as dependent spouse); and policies of sending and receiving countries. Jolly and Reeves (2005) further revealed that migrant women tend to dominate in unskilled sectors such as domestic workers 
and sex workers which may cause them to be at a greater risk of exploitation. On the other hand, migrant men often dominate in more regulated sectors such as construction, mines and agriculture.

Human capital (education) is another driving force causing people to migrate. Individuals with high level of education are likely to migrate more than those who are not educated or have lower levels of education because of economic returns at destination. According to Bustamante et al. (1998) this pattern occurs due to high economic returns and employment opportunities in the country facing in-migration. Educated people migrate from developing to developed countries in search of work, business opportunities and possible high earnings. If more educated people leave their countries of origin, it may eventually lead to brain drain. According to Kanbur and Rapoport (2003) brain drain may later induce positive feedback effects such as remittances and return migration after having obtained additional skills from abroad.

The movement of people within and between countries often happens as a result of connection between family and friends. As a result, the more people are connected the greater in-migration flow increases at destination. Therefore, migration selectivity on marital status may be a result of the migration network theory. A person's marital status may have implications on many decisions. Migration is usually associated with married people as they need to support families. The married spouse tends to migrate more to join their partners at destination. A family usually plays a role or rather has an influence on who migrates, to where, and for how long (Bueker 2004). When migrating as a single person or independently, the process of finding a job, acquiring a visa and finding a decent location to reside in may be difficult and take longer. Thus, migrating as part of a family may encourage stronger incorporation at the country of destination (Bueker 2004).

\section{Research Methods}

This paper makes use of a cross-sectional design and correlational analysis which attempts to understand patterns of relationships between variables. In assessing the structural changes of African migrants in the labour force of South Africa, this paper makes use of the 2001 and 2011 population censuses conducted by Statistics South Africa. A 10\% sample data was weighed to make 
statistical inference for the population. Both census files were obtained in SPSS format. The accessibility of data in SPSS format made it possible to run necessary statistical analysis.

This study focuses on African migrants who migrated to South Africa in search for employment opportunities based on 2001 and 2011 census data. Since this study focuses on the participation of African migrants in the South African labour force, the participants under this study include all foreign African migrants both male and females who were living in South Africa. The study particularly focuses on African migrants who were economically active at the time of the censuses. The age group of interest for analytical purpose are those aged 15-64 years since these people make up the labour force. African migrants were selected by looking at their country of birth and citizenship status.

\section{Size and Distribution of African Immigrants}

Understanding the population structure for African migrants is important for policy planning purposes. From an economic point of view, the economically active population contributes to the productivity of the country through their provision of labour. Comparing the two periods, the results show that the active population of African migrants increased from 234841 (2001) to 880072 (2011) with an average annual growth rate of $13.2 \%$. The statistics in the Table below presents the percentage distribution of males which decreased from $78.1 \%$ to $69.6 \%$ whilst females increased from $21.9 \%$ to $30.4 \%$. Migration of women has always been an important factor in international migration. Even though, the percentage of females has increased over the period, it can be noted that the number of males remains higher than that of females. These results are in line with the migration selectivity theory which hypothesised that migrants are predominantly males. Migration patterns within and from Africa have recently became more feminised, i.e. females are migrating more in search for employment and to achieve their economic needs (UN 2004; Adepoju 2004).

\section{Age Structure of African Migrants}

Economic crises in countries often drives youth to make decisions to migrate with the purpose of finding better employment opportunities in foreign 
Structural Changes in the Participation of Migrants in the Labour Force countries. Young people often migrate in order to obtain higher education, finding work, getting married and family reunification (UN, 2011).

Table 1: Distribution of African Migrants Population by Gender in 2001 and 2011

\begin{tabular}{|c|c|c|c|c|c|c|}
\hline \multirow[t]{2}{*}{ Variable } & \multicolumn{2}{|c|}{2001} & \multicolumn{2}{|c|}{2011} & \multirow{2}{*}{$\begin{array}{c}\text { Percentage } \\
\text { Change } \\
(\mathbf{2 0 0 1 - 2 0 1 1 )}\end{array}$} & \multirow[b]{2}{*}{$\begin{array}{c}\text { Annual } \\
\text { Average } \\
\text { Growth } \\
\text { Rate } \\
\text { (2001- } \\
\text { 2011) }\end{array}$} \\
\hline & $\mathbf{N}$ & $\%$ & $\mathbf{N}$ & $\%$ & & \\
\hline Sex & & & & & & \\
\hline Male & 183462 & 78,1 & $\begin{array}{l}612 \\
554\end{array}$ & 69,6 & 233,9 & 12,1 \\
\hline Female & 51379 & 21,9 & $\begin{array}{l}267 \\
518\end{array}$ & 30,4 & 420,7 & 16,5 \\
\hline Total & 234841 & 100,0 & $\begin{array}{l}880 \\
072\end{array}$ & 100 & 274,8 & 13,2 \\
\hline
\end{tabular}

Source: Own computation using StatsSA 2001 and 2011 census data

Table 2 below tabulates the age distribution of African migrants for the year 2001 and 2011. Comparing the two periods, the table shows that most of the African migrants were relatively young, with a young population (15-34 years) of $59.8 \%$ in 2001 and $70.8 \%$ in 2011 . The statistics in the Table reveal that the proportion of young African migrants who entered the South African labour force increased between the two periods. This shows that most of African migrants in the country were fairly young. It appears that the migrants in the 
15-34 age category have been growing at a faster annual average growth rate than the rest of the African migrants. On the other hand, the findings show that the proportion of the 35-39 years age group remained fairly constant at about $13 \%$ between the two census periods. In sharp contrast to the increase in the youth migrants, the remaining population in the labour force (from ages of 3564 years) show a decline from $40.2 \%$ in 2001 to $29.2 \%$ in 2011. The decrease in the proportion of older people in the labour force may be due to the high growth in youth participation. From the outcome of these results it is evident that migration is selective when it comes to age, that is, migration brings more migrants in the early working age than those in the advanced ages. The possible explanation is that young people migrate more than those in the older age groups in search for employment opportunities while others migrate to obtain education and possibly seek work upon completing their studies.

\section{Table 2: Age Distribution of African Migrants in 2001 and 2011}

\begin{tabular}{|c|c|c|c|c|c|c|}
\hline \multirow[t]{2}{*}{ Variable } & \multicolumn{2}{|c|}{2001} & \multicolumn{2}{|c|}{2011} & \multirow{2}{*}{$\begin{array}{l}\text { Percentage } \\
\text { change } \\
(2001-2011)\end{array}$} & \multirow{2}{*}{$\begin{array}{c}\text { Annual } \\
\text { Average } \\
\text { Growth } \\
\text { rate (2001- } \\
\text { 2011) } \\
\end{array}$} \\
\hline & $\mathbf{N}$ & $\%$ & $\mathbf{N}$ & $\%$ & & \\
\hline \multicolumn{7}{|l|}{ Age group } \\
\hline $15-19$ & $\begin{array}{r}10 \\
722 \\
\end{array}$ & 4,6 & $\begin{array}{r}30 \\
762 \\
\end{array}$ & 3,5 & 186,9 & 10,5 \\
\hline $20-24$ & $\begin{array}{r}39 \\
312 \\
\end{array}$ & 16,7 & $\begin{array}{l}165 \\
842\end{array}$ & 18,8 & 321,9 & 14,4 \\
\hline $25-29$ & $\begin{array}{r}52 \\
045 \\
\end{array}$ & 22,2 & $\begin{array}{l}244 \\
122 \\
\end{array}$ & 27,7 & 369,1 & 15,5 \\
\hline $30-34$ & $\begin{array}{r}38 \\
221\end{array}$ & 16,3 & $\begin{array}{l}183 \\
479\end{array}$ & 20,8 & 380,0 & 15,7 \\
\hline $35-39$ & $\begin{array}{r}31 \\
283 \\
\end{array}$ & 13,3 & $\begin{array}{l}115 \\
777\end{array}$ & 13,2 & 270,1 & 13,1 \\
\hline $40-44$ & $\begin{array}{r}25 \\
568 \\
\end{array}$ & 10,9 & $\begin{array}{r}63 \\
142 \\
\end{array}$ & 7,2 & 147,0 & 9,0 \\
\hline $45-49$ & $\begin{array}{r}18 \\
932 \\
\end{array}$ & 8,1 & $\begin{array}{r}36 \\
434 \\
\end{array}$ & 4,1 & 92,4 & 6,5 \\
\hline $50-54$ & $\begin{array}{r}11 \\
758\end{array}$ & 5,0 & $\begin{array}{r}23 \\
132\end{array}$ & 2,6 & 96,7 & 6,8 \\
\hline
\end{tabular}


Structural Changes in the Participation of Migrants in the Labour Force

\begin{tabular}{|l|r|r|r|r|r|r|}
\hline $55-59$ & 4694 & 2,0 & 414 & 1,4 & 164,5 & 9,7 \\
\hline $60-64$ & 2307 & 1,0 & 4969 & 0,6 & 115,4 & 7,7 \\
\hline & $\mathbf{2 3 4}$ & & $\mathbf{8 8 0}$ & & & \\
Total & $\mathbf{8 4 1}$ & $\mathbf{1 0 0 , 0}$ & $\mathbf{0 7 2}$ & $\mathbf{1 0 0 , 0}$ & $\mathbf{2 7 4 , 8}$ & $\mathbf{1 3 , 2}$ \\
\hline
\end{tabular}

Source: Own computation using StatsSA 2001 and 2011 census data

\section{Educational Status}

Educational status is used to measure available skills and creativity in the active population in order to perform labour activities. Furthermore, educational status has an influence on job opportunities. In the census data, 'no schooling' refers to all persons who did not have any form of formal education. Therefore, from the economically active population those with no schooling are classified as uneducated.

The 2001 census data revealed that the majority of migrants completed secondary schooling $(41.6 \%)$, followed by those with primary schooling $(32.3 \%)$ and lastly only $6.1 \%$ with tertiary education. Furthermore, the data showed that $20 \%$ of the migrants had no formal education hence classified as uneducated. The Figure 1 below reveals that there was no huge difference in the proportion of male and female migrants who had no formal education. African male migrants who completed primary education were higher in number than their female counterparts. However, the proportion of female migrants who completed secondary or tertiary education was higher than male migrants.

In comparison to the 2001 findings, the 2011 census data suggests that migrants who were part of the labour force were more educated. The population is still dominated by people with secondary education. The results indicate that there has been a major decline in African migrants with no schooling (uneducated) between the two census periods, from $20 \%$ in 2001 to $6.8 \%$ in 2011 . Initially, the decline in the proportion of those who had no formal education was positive because one of the 2015 Millennium Development Goals (MDG) was to make sure that individuals at least complete primary level of schooling. Secondly, it could be that migration attracted more persons with quality education during the ten-year period. Those with primary schooling also decreased from $32.3 \%$ in 2001 to $18.3 \%$ in 2011 . The proportion 
of those with secondary or tertiary education increased respectively. Inasmuch as the results show a positive change, only a few have completed tertiary education with an increase of about $3.6 \%$ between the two periods. Furthermore, the findings in Figure 1 show that in 2011 African male migrants who had no formal education or those who completed primary education were higher than females. Similar to 2001, the proportion of female migrants who completed secondary or tertiary education was higher than their male counterparts. In addition, the proportion of both males and females with no schooling or primary education decreased while those who completed secondary schooling or tertiary qualification showed an increase.

\section{Figure 1: Educational Status by Gender in 2001 and 2011}

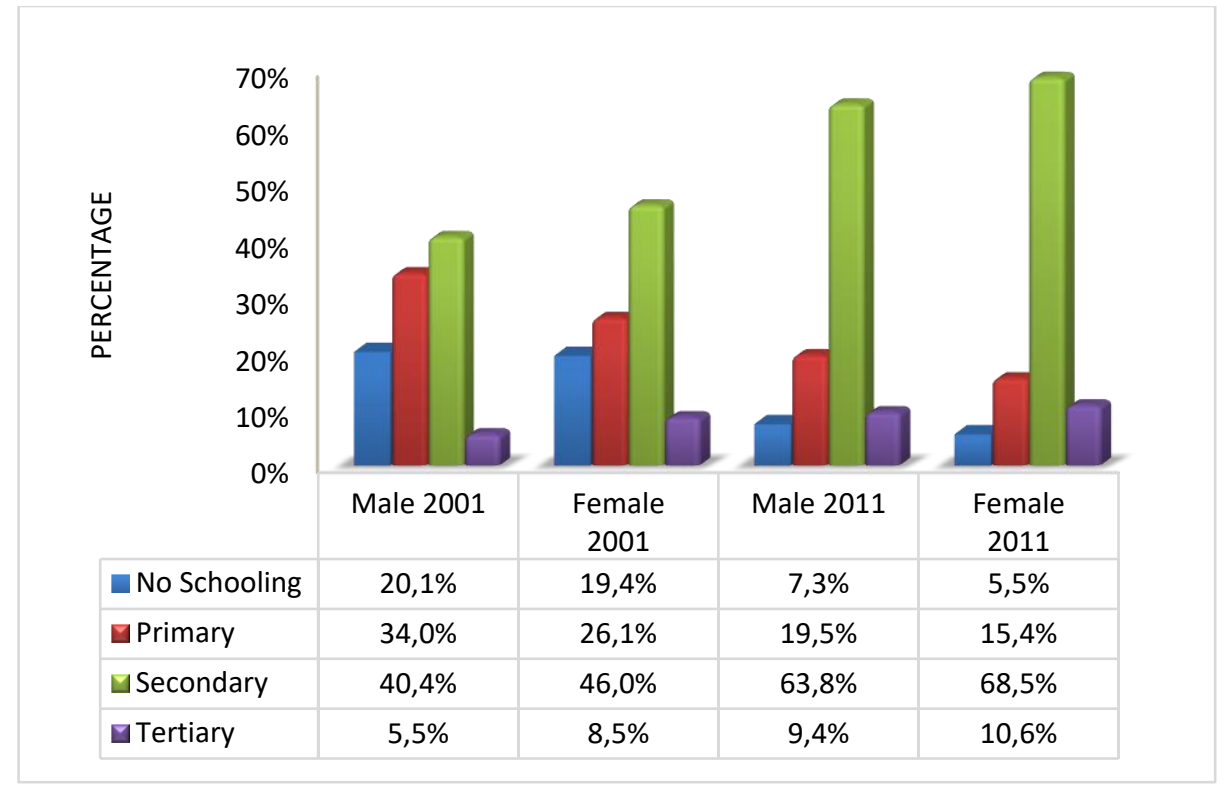

Source: Own computation using StatsSA 2001 and 2011 census data

In comparing the two periods, it seems evident that African migrants who were part of the labour force have become more educated between the two census periods. One of the MDG was to make sure that both males and females 
complete primary schooling. The decrease in migrants with no schooling or with primary schooling suggest that there was an increase in the proportion of those who completed secondary level of schooling and tertiary education. On the other hand, the decline in the proportion of no schooling and primary schooling may be attributed to the better educated persons migrating to South Africa. The increase in the level of educational status between the two census periods illustrate that migration brought migrants of quality which is in line with the migration selectivity theory that individuals with high level of education are more likely to migrate. Moreover, the figure indicates the presence of gender disparities in education with females being more educated than their male counterparts.

The analysis of educational Status among African migrants by age assists in understanding the long-term trends in education especially through comparing the younger with the older age groups. Figure 2 below shows trends in education within the ten-year period.

Figure 2: Educational Status by Age Group in 2001 and 2011

\begin{tabular}{|c|c|c|c|c|c|c|c|c|c|c|c|}
\hline \multirow{10}{*}{$\begin{array}{r}100 \% \\
90 \% \\
80 \% \\
70 \% \\
60 \% \\
50 \% \\
40 \% \\
30 \% \\
20 \% \\
10 \% \\
0 \%\end{array}$} & \multirow{10}{*}{$\begin{array}{c}15- \\
19 \\
\end{array}$} & \multirow{8}{*}{\multicolumn{2}{|c|}{ 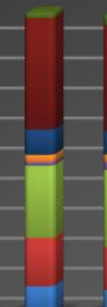 }} & f & \multirow{2}{*}{-1} & -7 & -1 & -1 & -1 & - & \multirow{4}{*}{ E } \\
\hline & & & & -1 & & -1 & - & - & $\longrightarrow$ & $\longrightarrow$ & \\
\hline & & & & & & 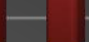 & - & - & 一 & $\longrightarrow$ & \\
\hline & & & & & & & & & & & \\
\hline & & & & & & & & & & & \\
\hline & & & & & & & & & & & \\
\hline & & & & & & & & & & & \\
\hline & & & & & 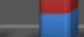 & 7 & -1 & & - & -1 & \\
\hline & & 20- & 25- & 30- & 35- & 40- & 45- & 50- & 55- & 60- & \\
\hline & & 24 & 29 & & 39 & 44 & & & 59 & & \\
\hline × Tertiary 2011 & $1,0 \%$ & $4,0 \%$ & $8,7 \%$ & $12,2 \%$ & $13,3 \%$ & $14,5 \%$ & $\% 14,7 \%$ & $12,3 \%$ & $\% 12,8 \%$ & $14,2 \%$ & \\
\hline ע Secondary 2011 & $66,7 \%$ & $74,2 \%$ & $670,4 \%$ & $65,0 \%$ & $61,3 \%$ & $655,9 \%$ & $\% 46,7 \%$ & $640,3 \%$ & $\% 37,4 \%$ & $39,1 \%$ & \\
\hline × Primary 2011 & $26,4 \%$ & $16,8 \%$ & $15,7 \%$ & $16,6 \%$ & $17,7 \%$ & $619,9 \%$ & $027,1 \%$ & $32,4 \%$ & $632,9 \%$ & $25,5 \%$ & \\
\hline — No Schooling 2011 & $5,9 \%$ & $4,9 \%$ & $5,1 \%$ & $6,1 \%$ & $7,7 \%$ & $9,6 \%$ & $11,6 \%$ & $15,0 \%$ & $16,9 \%$ & $21,2 \%$ & \\
\hline × Tertiary 2001 & $0,5 \%$ & $2,3 \%$ & $5,1 \%$ & $7,9 \%$ & $8,3 \%$ & $8,0 \%$ & $8,2 \%$ & $7,5 \%$ & $11,0 \%$ & $8,7 \%$ & \\
\hline * Secondary 2001 & $37,3 \%$ & $48,1 \%$ & $651,4 \%$ & $46,8 \%$ & $40,9 \%$ & $33,6 \%$ & $25,8 \%$ & $21,1 \%$ & $18,5 \%$ & $22,2 \%$ & \\
\hline × Primary 2001 & $39,3 \%$ & $32,1 \%$ & $28,4 \%$ & $26,4 \%$ & $32,9 \%$ & $36,2 \%$ & $638,5 \%$ & $39,8 \%$ & $637,8 \%$ & $32,2 \%$ & \\
\hline × No Schooling 2001 & $22,8 \%$ & $17,5 \%$ & $615,0 \%$ & $18,8 \%$ & $17,9 \%$ & $22,2 \%$ & $627,5 \%$ & $31,6 \%$ & $632,7 \%$ & $36,9 \%$ & \\
\hline
\end{tabular}

Source: Own computation using StatsSA 2001 and 2011 census data 
The data reveals that the majority of African migrants in the older age groups had no formal education as compared to those in the younger age groups. Most African migrants in the younger age groups completed primary or secondary level of education while the majority of migrants who completed tertiary education were found in the older age groups. However, the proportion of those who completed primary, secondary or tertiary education fluctuated with age. It is observed that the level of educational attainment increased with age among African migrants.

\section{Country of Birth}

The country of birth helped to identify the country from which the migrants have originated. Figure 3 below displays the top ten African countries from which migrants originated in 2001 and 2011. It will be observed that the main contributing countries between the two censuses were Mozambique, Zimbabwe and Lesotho. Mozambique contributed the largest proportion of immigrants in 2001 with $43.8 \%$, while Zimbabwe contributed the largest in 2011 with $45.2 \%$. The figures show a major increase of immigrants from Zimbabwe from $14.5 \%$ (2001) to $45.2 \%$ (2011).

Figure 3: Top Ten African Countries Contributing Migrants to South Africa

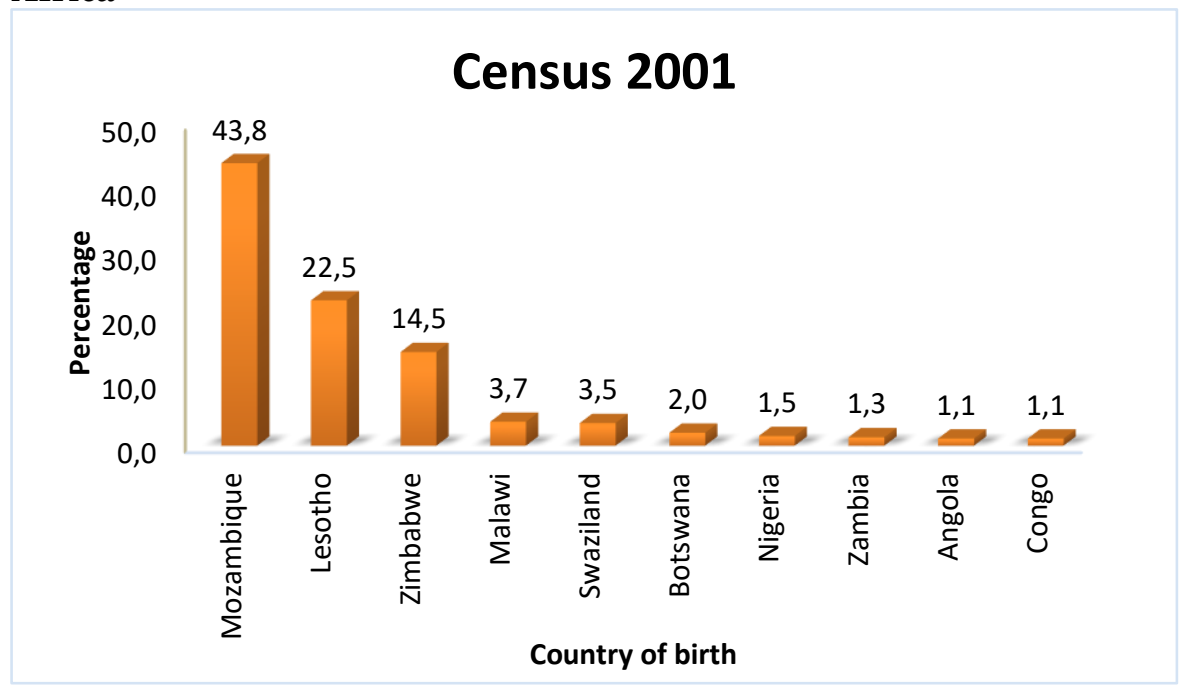




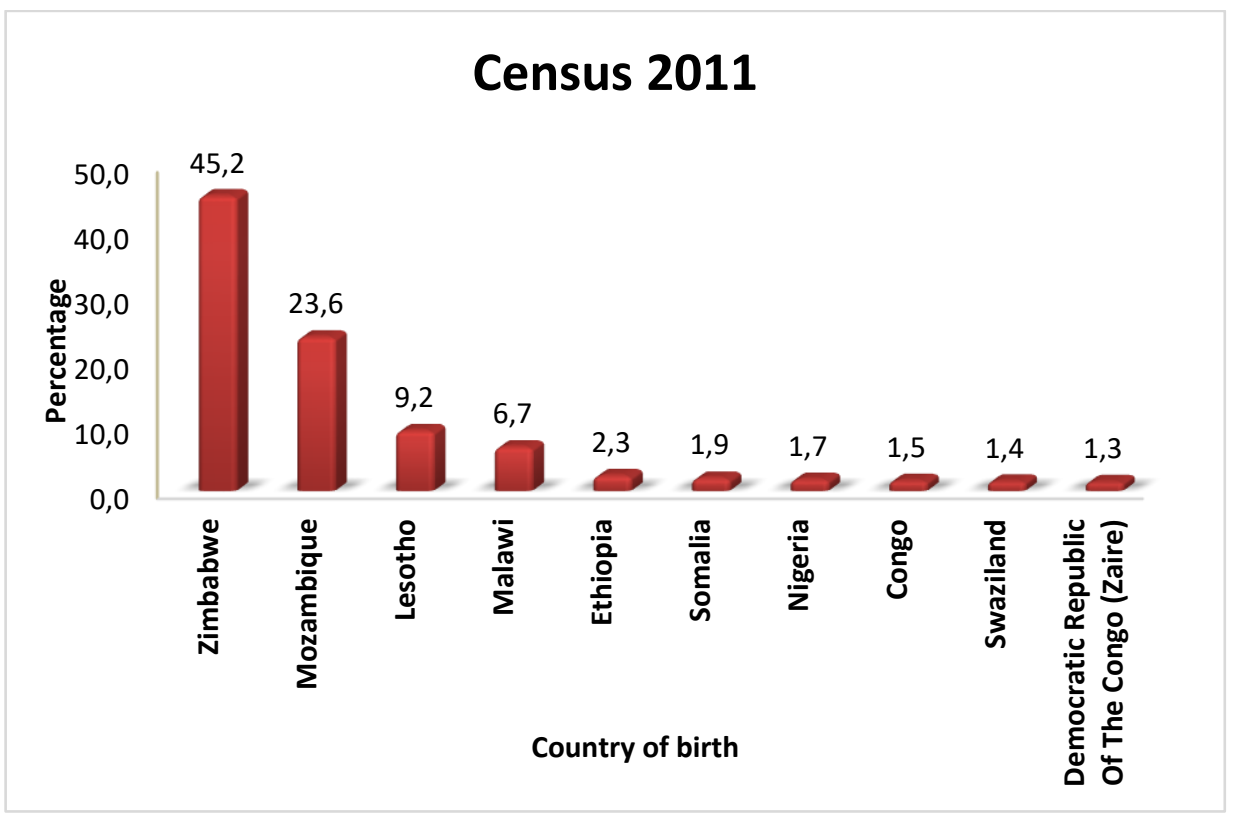

Source: Own computation using StatsSA 2001 and 2011 census data

\section{Migration Patterns in the Labour Force of South Africa}

This section profiles the socioeconomic characteristics of African migrants who were part of the labour force in South Africa between 2001 and 2011. The analysis of the socioeconomic characteristics is in terms of employment status, monthly income, occupation, industry, and type of sector.

\section{Employment Status}

Table 3 below shows the results for the African migrants working age population and labour force in 2001 and 2011. The findings reveals an increase in the number of the working age population and for those in the labour force (both the employed and unemployed increased). There was a small decrease of $0.1 \%$ in the Labour Force Participation Rate (LFPR) from $78.9 \%$ in 2001 to $78.8 \%$ in 2011, while the share of the unemployed African migrants decreased only by $2.2 \%$ over the two census periods. Furthermore there was a decrease 
in the unemployment rate from $23 \%$ to $20.1 \%$ while the employment rate increased from $77 \%$ (2001) to $79.9 \%$ (2011). The decrease in the unemployment rate complimented by an increase in employment rate suggests that the South African labour market was able to absorb new African migrants in the labour market between the two periods.

Table 3: Working Age Population and Labour Force Details, Census 2001 and 2011

\begin{tabular}{|l|r|r|}
\hline & \multicolumn{1}{|c|}{$\mathbf{2 0 0 1}$} & \multicolumn{1}{|c|}{$\mathbf{2 0 1 1}$} \\
\hline Working age & 297827 & 1116401 \\
\hline Employed & 180924 & 702763 \\
\hline Unemployed & 53917 & 177308 \\
\hline Labour Force & 234841 & 880071 \\
\hline Employment rate & 77,0 & 79,9 \\
\hline Unemployment rate & 23,0 & 20,1 \\
\hline Labour Force Participation Rate & 78,9 & 78,8 \\
\hline Labour Absorption Rate & 60,7 & 69,9 \\
\hline
\end{tabular}

Source: Own computation using StatsSA 2001 and 2011 census data

\section{Employment Status by Gender and Educational Attainment}

According to the 2001 population census, the proportion of employed males was higher than females regardless of educational attainment. The proportion of those employed increased with the level of education up to secondary education for both sexes. A large proportion of females with tertiary qualification were employed than those with no formal schooling. Moreover, the 2011 census reveal that the proportion of employed and unemployed migrants with no schooling decreased over the period.

Figure 4 below provides the results of the labour force participation rate by educational status. Between 2001 and 2011, the labour participation rate for African migrants who had no formal schooling or those who completed their primary education, decreased. However, there was an increase in the labour participation rate for African migrants who completed secondary or 
tertiary level education. Labour participation for those who attained tertiary education increased by 14.5 points within the ten years from $67.2 \%$ (2001) to $81.7 \%$ (2011). The 2011 census data suggest that African migrants with higher educational status were likely to be in the labour force supplying their labour for economic activities. However, the 2001 census results revealed that a high proportion of migrants who supplied their labour in the labour market were those who were uneducated (no schooling) and those who had completed primary schooling. Thus, over the year's education became an important criteria for African migrants to be in the labour force.

\section{Figure 4: Labour Force Participation Rate by Educational Status}

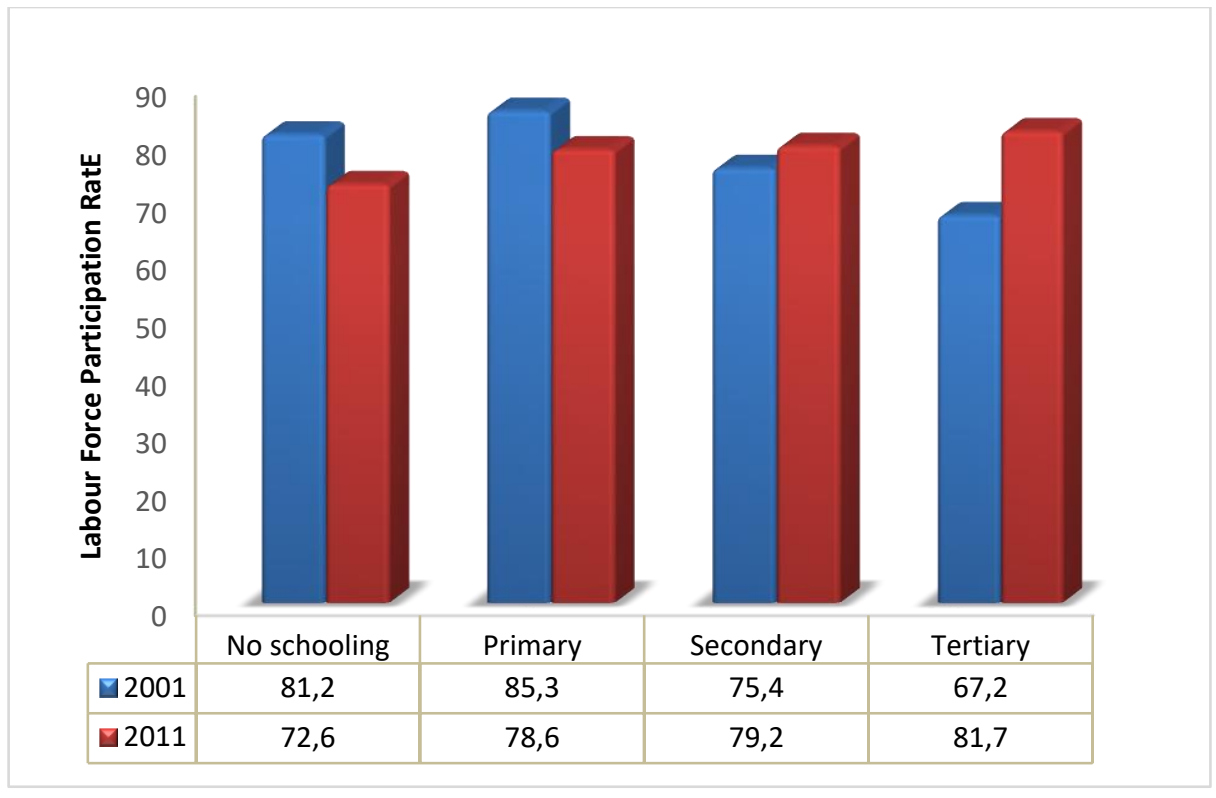

Source: Own computation using StatsSA 2001 and 2011 census data

\section{Monthly Income Category by Sex and Educational Status}

Generally, in the labour market education is related to income, that is, individuals who completed the highest level of education have the probability 


\section{Yamkela Majikijela and Gabriel Tati}

of earning higher incomes than those who have lower levels of education. According to Ghatak, Levine, \& Price (1996) migrants who have completed higher levels of education have higher earnings and increased employment probabilities than other immigrant workers. Furthermore, the neoclassical economics of migration theory suggest that labour migration is driven by income differences between countries. Individuals migrate because of high expected income in the country of destination. However, upon arrival at destination countries, migrants might not earn what they expected. The monthly income category is in nominal terms meaning that the income is not adjusted in terms of inflation.

The results for 2001 census revealed that there were African migrants (both sexes) who did not earn any monetary income in all levels of education, with females initially being higher than their male counterparts. Regardless of educational status, migrants who reported to have no income were both employed and unemployed. This suggest that there was a proportion of migrants who were employed but did not receive any income in monetary value. About $26.3 \%$ migrants who have attained tertiary level of education reported to have no income. Female African migrants either with no schooling, primary and secondary level of education earning in the monthly income bracket of R1-R400 were higher than males, while the proportion of males with tertiary level qualification was higher.

The proportion of males who had no formal schooling and those who completed primary or secondary level of education earned in the monthly income bracket of R401 to R25600 was more than that for females. However, the proportion of females who attained tertiary level education was higher than their male counterparts. These results may suggest that for females to earn in the higher income bracket they need to be better educated. For the monthly income category of R51201 and more, both males and females with no schooling or with primary education were less represented than those with secondary or tertiary level. The proportion of males with secondary or tertiary education was higher than females even though there was a minimal difference. Nonetheless, males were more represented in higher earnings than their female counterparts.

A similar trend as above for the 2001 results has been observed where both males and females migrants with no income are represented in all levels of education. Between the two census periods the results indicate that there has been a decrease in the proportion of males with no schooling or primary 
education and earning no income. Females who attained the tertiary level of education indicated a sharp increase. In the monthly income group of R1-R400 there were more males than females in 2011. However, the proportion of both males and females earning this income bracket decreased during the ten-year period. Males earning in the monthly income bracket of R401-R51200 were higher in proportion than their female counterparts. Furthermore, the results reveal that males were earning higher than females in the higher income category regardless of their educational attainment.

Overall, the results reveal that income earned by both males and females increases with level of education. This suggests that migrants who completed secondary schooling or tertiary education are more represented in the higher income brackets (from R3201 and above). Also, the results show that there are gender disparities in monthly earnings.

\section{Employment by Occupation}

The Table 4 below present's findings for employed migrants by occupation in 2001 and 2011 census years. Comparing the two periods, the statistics in the Table below reveal that there has been an increase in African migrants who were employed in professional, high skilled occupation namely; managers, professionals, technicians, clerks, and service workers. Moreover, a proportion of those employed in the low skilled occupations have decreased. Therefore, this means that during the period there were more African migrants who joined the high skilled occupation. Looking at the 2001 results, the majority of African migrants were employed in elementary occupations $(32.4 \%)$, followed by craft workers $(26.7 \%)$ and machine operators $(14.1 \%)$. Inasmuch as these results indicate a decrease in these occupations, a similar trend is observed in 2011 where majority of migrants were employed in elementary occupations $(19.3 \%)$, craft workers $(17.7 \%)$, service workers $(17.8 \%)$ and domestic workers accounted for $11.5 \%$. Nonetheless, a proportion of migrant workers who are employed as service workers and as craft workers in 2011 was equivalent. 
Yamkela Majikijela and Gabriel Tati

Table 4: Employment by Occupation in 2001 and 2011

\begin{tabular}{|l|r|r|r|r|}
\hline \multirow{2}{*}{ Occupation } & \multicolumn{2}{|c|}{$\mathbf{2 0 0 1}$} & \multicolumn{2}{c|}{$\mathbf{2 0 1 1}$} \\
\cline { 2 - 5 } & Frequency & \multicolumn{1}{|c|}{ Percent } & Frequency & Percent \\
\hline Managers & 4405 & 2,6 & 44424 & 6,3 \\
\hline Professionals & 7893 & 4,6 & 35234 & 5,0 \\
\hline Technicians & 4874 & 2,9 & 41758 & 5,9 \\
\hline Clerks & 5407 & 3,2 & 59232 & 8,4 \\
\hline Service workers & 15461 & 9,1 & 125031 & 17,8 \\
\hline Skilled agricultural & 7675 & 4,5 & 5987 & 0,9 \\
\hline Craft workers & 45558 & 26,7 & 124468 & 17,7 \\
\hline Machine operators & 23975 & 14,1 & 49686 & 7,1 \\
\hline Elementary occupations & 55152 & 32,4 & 135714 & 19,3 \\
\hline Domestic works & & & 81058 & 11,5 \\
\hline Total & $\mathbf{1 7 0} \mathbf{4 0 2}$ & $\mathbf{1 0 0}$ & $\mathbf{7 0 2} \mathbf{5 9 2}$ & $\mathbf{1 0 0}$ \\
\hline
\end{tabular}

Source: Own computation using StatsSA 2001 and 2011 census data

To gain a better insight on the above section, Figure 5 below has been presented in terms of occupation and sex. Both sexes employed in high skilled professional occupations have increased during the period of 2001-2011 however females who were employed as professionals showed a decrease. Females who worked as managers, professionals, technicians, clerks and service workers were higher than males in 2001. Nonetheless, the 2011 results indicate that males employed as managers and service workers were higher in proportion than females. In contrast to the high skilled professional occupations, the results for low skilled occupations reveal that the proportion of both males and females decreased during the period. However, females in the elementary occupations show an increase. Furthermore, the 2011 results show that there were African migrants who worked as domestic workers (in 2001 the variable was not available). The proportion of females who worked as domestic workers was higher than that for males. 
Structural Changes in the Participation of Migrants in the Labour Force

\section{Figure 5: Employment by Occupation and Gender in 2001 and 2011}

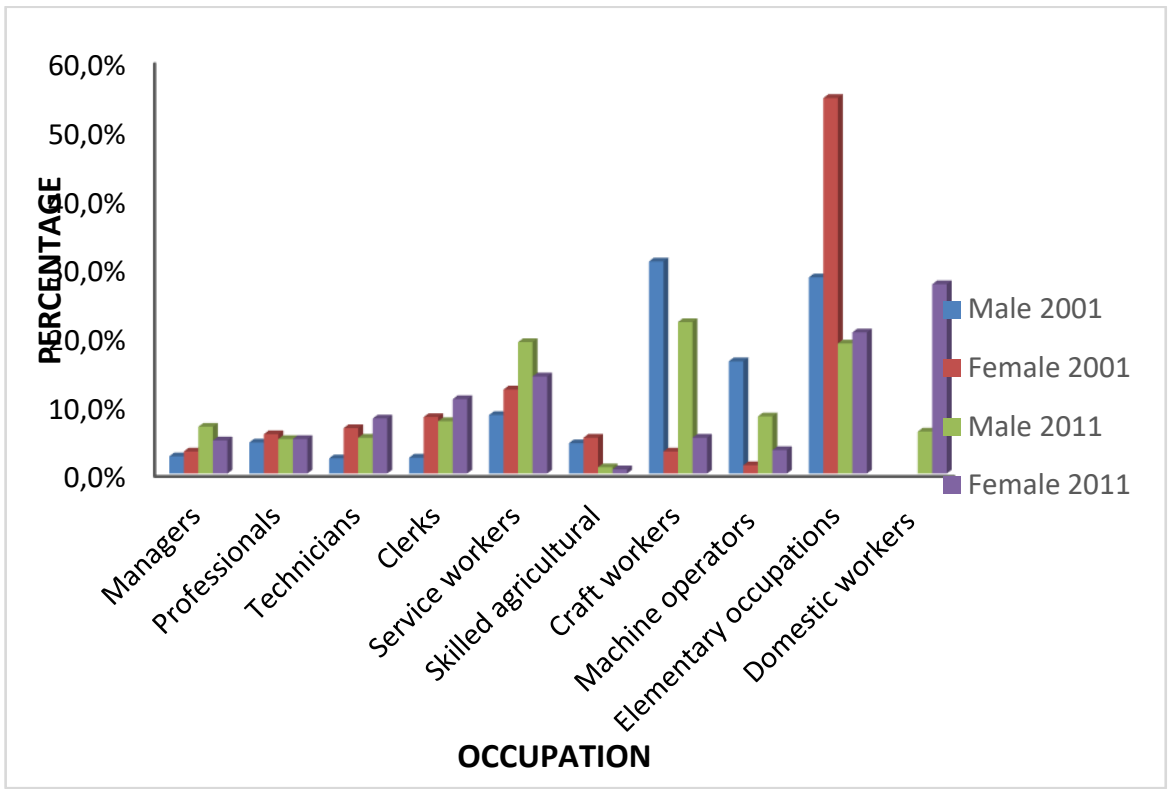

Source: Own computation using StatsSA 2001 and 2011 census data

\section{Occupation by Gender and Educational Status}

The results reveal that the majority of migrants who were employed in skilled occupation such as managers, professionals, technicians and clerks had attained tertiary level education followed by those who completed a secondary education. Therefore, migrants with no formal education or with primary education accounted for a small share in the high skilled occupations. Regardless of the level of education, the proportion of African male migrants who were employed as managers and professionals was predominantly higher than that of females while majority of females were employed as technicians and clerks. Furthermore, majority of African migrants who were employed as craft workers, skilled agricultural, machine operators and in elementary occupations had no schooling, followed by those who completed primary and secondary education. In addition, migrants with tertiary education accounted 
for a small proportion. A higher proportion of females worked in the elementary occupations except for those who completed tertiary level of education.

A similar trend with the 2001 results has been observed. The 2011 results revealed that Majority of African migrants who completed a tertiary level of education worked in the high skilled professional occupations while migrants with no schooling, primary and secondary education were employed in the remaining occupations. Moreover, the results reveal that more males than females were still employed in high skilled professional occupations while more females were employed in the low skilled occupations. There has been a decline in the proportion of those with a tertiary education (both male and female) who were employed as professionals and technicians during the period. Migrants who were employed as clerks have increased across all levels of education. Results also show that there has been a small increase in the proportion of African migrants who had primary, secondary and those with no education who entered high skilled occupations. Furthermore, migrants in the elementary occupations have decreased. The occupation 'domestic workers' was not available in 2001 however in 2011 this occupation was available. Henceforth, majority of migrants who were employed as domestic workers had no schooling, primary and those with secondary education; a small share had tertiary level education. This indicates that there were difficulties for migrants who attained tertiary level education to find better jobs as a result they ended up working as domestic workers in order to make a living.

\section{Employment by Industry}

Table 5 below presents findings for employed African migrants by industry between 2001 and 2011. The results reveal that in 2001 majority of African migrants were employed in mining (34.8\%), agriculture (19.2\%) and $13 \%$ were employed in wholesale businesses. In contrast to the 2001 results, there were variations in the employment of migrants within the industries. The 2011 census results reveal that majority of migrants were employed in wholesale businesses (20.6\%), private household (14.6\%), community service (14.1\%), financial services (13\%) and $12.7 \%$ were employed in the construction industry. Overall, there was a sharp decline in the proportion of African migrants who were employed in the agriculture and mining industries during the ten-year period. 
Structural Changes in the Participation of Migrants in the Labour Force

Table 5: Employment by Industry in 2001 and 2011

\begin{tabular}{|l|r|r|r|r|}
\hline \multirow{2}{*}{ Industry } & \multicolumn{2}{|c|}{$\mathbf{2 0 0 1}$} & \multicolumn{2}{c|}{ 2011 } \\
\cline { 2 - 5 } & Frequency & \multicolumn{1}{|c|}{ Percent } & \multicolumn{1}{c|}{ Frequency } & \multicolumn{1}{c|}{ Percent } \\
\hline Agriculture & 32176 & 19,2 & 50932 & 7,2 \\
\hline Mining & 58216 & 34,8 & 28008 & 4,0 \\
\hline Manufacturing & 10851 & 6,5 & 59346 & 8,4 \\
\hline Electricity & 424 & 0,3 & 4079 & 0,6 \\
\hline Construction & 13010 & 7,8 & 88969 & 12,7 \\
\hline Wholesale & 21807 & 13,0 & 144932 & 20,6 \\
\hline Transport & 3193 & 1,9 & 32785 & 4,7 \\
\hline Financial services & 7356 & 4,4 & 91614 & 13,0 \\
\hline Community services & 9576 & 5,7 & 98913 & 14,1 \\
\hline Private household & 10386 & 6,2 & 102672 & 14,6 \\
\hline Other & 198 & 0,1 & 342 & 0,0 \\
\hline Total & 167195 & 100 & 702592 & 100 \\
\hline
\end{tabular}

Source: Own computation using StatsSA 2001 and 2011 census data

In addition to the data in the Table above, Figure 6 below illustrate results for industries and gender. The 2001 results reveal that majority of males were employed in mining, manufacturing, electricity, construction and transport as compared to their female counterparts. The 2011 findings revealed that females who were employed in community services and private households industries were higher than males whilst the share of males was higher than females in the remaining industries. However, the proportion between males and females who were employed in the same industries were minimal. Inasmuch there has been an increase in the proportion of migrants who were employed in most of the industries except in agriculture and mining, females employed in manufacturing remained constant at $5.7 \%$ during the period. Furthermore, females in the mining industry increased in a small share from $1.1 \%$ to $1.3 \%$. 
Figure 6: Employment by Industry and Gender in 2001 and 2011

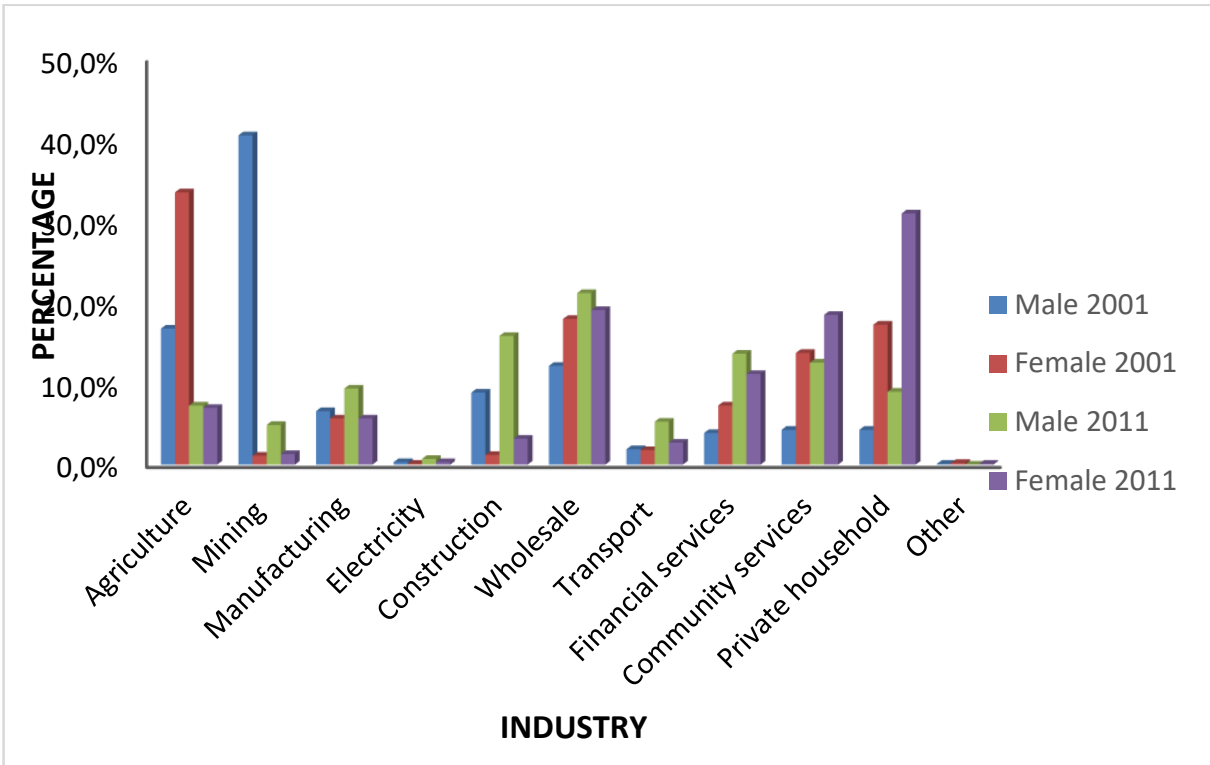

Source: Own computation using StatsSA 2001 and 2011 census data

\section{Industry by Gender and Educational Status}

The finding suggest that African female migrants who were employed in agriculture, community and private households industries were higher in proportion than males in all levels of education. Regardless of educational attainment a proportion of African male migrants employed in mining, manufacturing, electricity and construction industries were higher compared to females. The 2001 results also revealed that females who had no formal education and those with primary or secondary level of education were not employed in the electricity industry. However, only a small share of those who completed tertiary education was employed in this industry. These results suggest that females had little access to the electricity industry, which may be attributed to the nature of skills required to perform the job.

In comparison to the 2001 findings, the results suggest that there has been an increase in the proportion of African migrants (both sexes) who were 
employed in construction, transport, financial, community and private household industries across all levels of education. Moreover, changes in the proportion of migrants who were employment in the following industries: agriculture, mining, manufacturing, and electricity varied according to the level of educational achievement.

\section{Employment by Type of Sector}

The statistics in Figure 7 below indicate that African migrants were employed in all three sectors. The Table show that the majority $(58.0 \%)$ of African migrants were employed in the formal sector, followed by $21.4 \%$ of migrants who were employed in the informal sector. On the other hand, 20.6\% were employed in private households. Nonetheless, the difference between those in the informal sector and private household was minimal. In addition the share of males employed in the formal sector and informal sector was higher than that for females. On the other hand, females who worked in the private household sector were higher in proportion than males.

\section{Figure 7: Employment by Type of Sector and Gender in 2011}

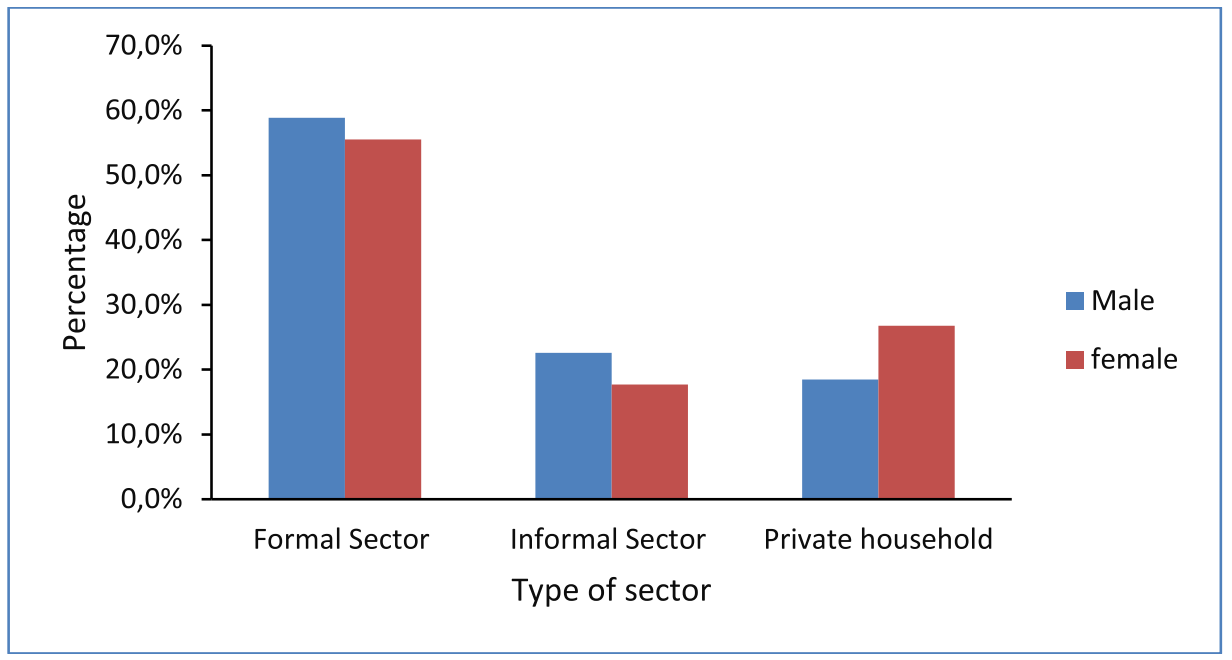

Source: Own computation using StatsSA 2011 census data 


\section{Type of Sector by Gender and Educational Status}

The statistics in Table 6 below depicts results for the type of sector by gender and educational achievement among African migrants in 2011. The results indicate that majority of African migrants who were employed in the formal sector completed tertiary education, followed by those who completed secondary levels of education. Furthermore, majority of migrants who were employed in the informal sector had no formal schooling, including who completed primary education. The proportion of males employed in the formal and informal sector was higher than females regardless of their level of education. Irrespective of the level of education, the majority of females were employed in the private household. The results show that a share of migrants employed in private households completed primary and secondary levels of education. Shown by the results, is that males (13.5\%) and females (15.4\%) who completed tertiary education were employed in private households.

\section{Table 6: Type of Sector by Gender and Educational Status in 2011}

\begin{tabular}{|c|c|c|c|c|c|c|c|c|}
\hline \multirow{3}{*}{$\begin{array}{l}\text { Type of } \\
\text { Sector }\end{array}$} & \multicolumn{8}{|c|}{ Educational Status } \\
\hline & \multicolumn{2}{|c|}{ No Schooling } & \multicolumn{2}{|c|}{$\begin{array}{c}\text { Primary } \\
\text { Education } \\
\end{array}$} & \multicolumn{2}{|c|}{$\begin{array}{l}\text { Secondary } \\
\text { Education } \\
\end{array}$} & \multicolumn{2}{|c|}{$\begin{array}{c}\text { Tertiary } \\
\text { Education } \\
\end{array}$} \\
\hline & Male & Female & Male & Female & Male & Female & Male & Female \\
\hline Formal & 17993 & 4325 & 52685 & 11107 & 187483 & 63604 & 39589 & 17397 \\
\hline Sector & $49.1 \%$ & $47.6 \%$ & $52.9 \%$ & $45.3 \%$ & $56.0 \%$ & $52.3 \%$ & $74.3 \%$ & $74.1 \%$ \\
\hline Informal & 10713 & 2538 & 25175 & 5262 & 73032 & 20925 & 5399 & 2056 \\
\hline Sector & & $27.9 \%$ & $25.3 \%$ & $21.5 \%$ & $21.8 \%$ & $17.2 \%$ & $10.1 \%$ & $8.8 \%$ \\
\hline Private & 6443 & 2016 & 18456 & 7321 & 61568 & 33511 & 7182 & 3618 \\
\hline $\begin{array}{c}\text { House- } \\
\text { hold }\end{array}$ & $17.6 \%$ & $22.2 \%$ & $18.5 \%$ & $29.9 \%$ & $18.4 \%$ & $27.6 \%$ & $13.5 \%$ & $15.4 \%$ \\
\hline Do not & 1521 & 203 & 3364 & 807 & 12478 & 3517 & 1084 & 393 \\
\hline Know & $4.1 \%$ & $2.2 \%$ & $3.4 \%$ & $3.3 \%$ & $3.7 \%$ & $2.9 \%$ & $2.0 \%$ & $1.7 \%$ \\
\hline TOTAL & 36670 & 9082 & 99680 & 24497 & 334561 & 121557 & 53254 & 23464 \\
\hline & $100 \%$ & $100 \%$ & $100 \%$ & $100 \%$ & $100 \%$ & $100 \%$ & $100 \%$ & $100 \%$ \\
\hline
\end{tabular}

Source: Own computation using StatsSA 2011 census data 
Structural Changes in the Participation of Migrants in the Labour Force

\section{Logistic Regression Analysis for African Migrants Employment} Status

Table 7 below depicts multivariate analysis results for African migrant's employment status for 2001 and 2011. The results show that age, sex and educational attainment are significantly associated (p-value<0.05) with employment status. With regards to the 2001 results, sex and age are strongly associated with employment status. The findings reveal that African female migrants were 0.202 less likely to be employed than their male counterparts.

Table 7: Binary Logistic Regression for African Migrants Employment Status

\begin{tabular}{|c|c|c|c|c|c|c|c|c|}
\hline \multirow[b]{2}{*}{ Variable } & \multicolumn{4}{|c|}{2001} & \multicolumn{4}{|c|}{2011} \\
\hline & B & Wald & Sig & $\begin{array}{l}\text { Exp } \\
\text { (B) }\end{array}$ & B & Wald & Sig & $\begin{array}{l}\text { Exp } \\
\text { (B) }\end{array}$ \\
\hline Constant & $\begin{array}{l}0 . \\
869\end{array}$ & $\begin{array}{l}401 . \\
021\end{array}$ & $\begin{array}{l}\text { 0. } \\
000\end{array}$ & $\begin{array}{l}2 . \\
386\end{array}$ & $\begin{array}{l}0 . \\
632\end{array}$ & $\begin{array}{l}1023 . \\
967\end{array}$ & $\begin{array}{l}\text { 0. } \\
000\end{array}$ & $\begin{array}{l}1 . \\
882\end{array}$ \\
\hline \multicolumn{9}{|l|}{ Sex } \\
\hline Male ${ }^{\circledR}$ & & & & 1 & & & & 1 \\
\hline Female & $\begin{array}{l}1.60 \\
1\end{array}$ & $\begin{array}{l}17535.1 \\
55\end{array}$ & $\begin{array}{l}0.00 \\
0\end{array}$ & $\begin{array}{l}0.20 \\
2\end{array}$ & $\begin{array}{l}1.08 \\
3\end{array}$ & $\begin{array}{l}35696.2 \\
00\end{array}$ & $\begin{array}{l}0.00 \\
0\end{array}$ & $\begin{array}{l}0.33 \\
8\end{array}$ \\
\hline \multicolumn{9}{|l|}{ Age } \\
\hline & & 4786.05 & 0.00 & & & 13024.3 & 0.00 & \\
\hline $15-19$ @ & 1 & 0 & 0 & 1 & 1 & 91 & & 1 \\
\hline $20-24$ & 4 & 34.382 & 0 & $\begin{array}{l}1.15 \\
4\end{array}$ & $\begin{array}{l}0.49 \\
6\end{array}$ & 2 & 0.00 & $\begin{array}{l}1.04 \\
2\end{array}$ \\
\hline & 0.61 & & 0.00 & 1.84 & 0.87 & 4089.11 & 0.00 & 2.40 \\
\hline $25-29$ & 4 & 621.579 & 0 & 7 & 6 & 2 & 0 & 2 \\
\hline & 0.72 & & 0.00 & 2.05 & 1.06 & 5515.60 & 0.00 & 2.88 \\
\hline $30-34$ & 0 & 751.542 & 0 & 5 & 1 & 3 & 0 & 9 \\
\hline & 1.00 & 1269.61 & 0.00 & 2.72 & 1.19 & 6011.48 & 0.00 & 3.29 \\
\hline $35-39$ & 3 & 6 & 0 & 7 & 2 & 3 & 0 & 3 \\
\hline & 1.12 & 1416.74 & 0.00 & 3.09 & 1.22 & 4981.75 & 0.00 & 3.39 \\
\hline $40-44$ & 9 & 8 & 0 & 3 & 3 & 9 & 0 & 6 \\
\hline & 1.45 & 1858.08 & 0.00 & 4.29 & 1.35 & 4441.42 & 0.00 & 3.88 \\
\hline $45-49$ & 6 & 7 & 0 & 1 & 8 & 3 & 0 & 7 \\
\hline
\end{tabular}


Yamkela Majikijela and Gabriel Tati

\begin{tabular}{|c|c|c|c|c|c|c|c|c|}
\hline $\begin{array}{r}50-54 \\
55-59 \\
60-64 \\
\end{array}$ & $\begin{array}{l}1.48 \\
6 \\
1.49 \\
8 \\
1.27 \\
8 \\
\end{array}$ & $\begin{array}{l}1421.06 \\
5 \\
743.042\end{array}$ & $\begin{array}{l}0.00 \\
0 \\
0.00 \\
0 \\
0.00 \\
0 \\
\end{array}$ & $\begin{array}{l}4.42 \\
0 \\
4.47 \\
3 \\
3.59 \\
0 \\
\end{array}$ & $\begin{array}{l}1.46 \\
2 \\
1.49 \\
9 \\
1.46 \\
8 \\
\end{array}$ & $\begin{array}{l}3713.35 \\
8 \\
2335.14 \\
3 \\
1019.81 \\
0 \\
\end{array}$ & $\begin{array}{l}0.00 \\
0 \\
0.00 \\
0 \\
0.00 \\
0 \\
\end{array}$ & $\begin{array}{l}4.31 \\
6 \\
4.47 \\
9 \\
4.34 \\
1 \\
\end{array}$ \\
\hline \multicolumn{9}{|c|}{ Marital Status } \\
\hline Married ® & $\begin{array}{c}1 \\
- \\
0.35\end{array}$ & $\begin{array}{l}1807.02 \\
9\end{array}$ & $\begin{array}{l}0.00 \\
0 \\
0.00\end{array}$ & $\begin{array}{c}1 \\
0.70\end{array}$ & $\begin{array}{c}1 \\
- \\
0.26\end{array}$ & $\begin{array}{l}2773.83 \\
7 \\
1166.49\end{array}$ & $\begin{array}{l}0.00 \\
0\end{array}$ & 0.77 \\
\hline Cohabiting & & 480.429 & 0 & 0 & 1 & 4 & 0 & 0 \\
\hline $\begin{array}{l}\text { Never } \\
\text { married }\end{array}$ & $\begin{array}{l}0.57 \\
5 \\
-\end{array}$ & $\begin{array}{l}1761.20 \\
2\end{array}$ & $\begin{array}{l}0.00 \\
0\end{array}$ & $\begin{array}{l}0.56 \\
3\end{array}$ & $\begin{array}{l}0.05 \\
9\end{array}$ & 76.958 & $\begin{array}{l}0.00 \\
0\end{array}$ & $\begin{array}{l}1.06 \\
1\end{array}$ \\
\hline Widowed & $\begin{array}{l}0.23 \\
8 \\
-\end{array}$ & 24.287 & $\begin{array}{l}0.00 \\
0\end{array}$ & $\begin{array}{l}0.78 \\
8\end{array}$ & $\begin{array}{l}0.48 \\
9\end{array}$ & 266.880 & $\begin{array}{l}0.00 \\
0\end{array}$ & $\begin{array}{l}1.63 \\
1\end{array}$ \\
\hline Divorced & $\begin{array}{l}0.52 \\
6 \\
- \\
0.13 \\
0 \\
\end{array}$ & 92.356 & $\begin{array}{l}0.00 \\
0 \\
0.01 \\
3 \\
\end{array}$ & $\begin{array}{l}0.59 \\
1 \\
0.87 \\
9 \\
\end{array}$ & $\begin{array}{l}0.15 \\
0 \\
1.05 \\
2 \\
\end{array}$ & 506.380 & $\begin{array}{l}0.00 \\
0 \\
0.00 \\
0 \\
\end{array}$ & $\begin{array}{l}1.16 \\
2 \\
2.86 \\
4 \\
\end{array}$ \\
\hline \multicolumn{9}{|c|}{ Educational attainment } \\
\hline $\begin{array}{l}\text { No } \\
\text { Schooling }\end{array}$ & & 2073.26 & 0.00 & & & 6494.87 & 0.00 & \\
\hline ® & $\begin{array}{c}1 \\
0.37\end{array}$ & 1 & $\begin{array}{l}0 \\
0.00\end{array}$ & $\begin{array}{c}1 \\
1.46\end{array}$ & $\begin{array}{c}1 \\
0.19\end{array}$ & 5 & $\begin{array}{l}0 \\
0.00\end{array}$ & $\begin{array}{c}1 \\
1.21\end{array}$ \\
\hline Primary & $\begin{array}{l}9 \\
0.49\end{array}$ & $\begin{array}{l}596.347 \\
1085.15\end{array}$ & $\begin{array}{l}0 \\
0.00\end{array}$ & $\begin{array}{l}1 \\
1.64\end{array}$ & $\begin{array}{l}2 \\
0.46\end{array}$ & $\begin{array}{l}259.329 \\
1767.35\end{array}$ & $\begin{array}{l}0 \\
0.00\end{array}$ & $\begin{array}{l}2 \\
1.58\end{array}$ \\
\hline $\begin{array}{l}\text { Secondary } \\
\text { Tertiary }\end{array}$ & $\begin{array}{l}9 \\
1.25 \\
0 \\
\end{array}$ & $\begin{array}{l}2 \\
1717.98 \\
4 \\
\end{array}$ & $\begin{array}{l}0 \\
0.00 \\
0 \\
\end{array}$ & $\begin{array}{l}7 \\
3.48 \\
9 \\
\end{array}$ & $\begin{array}{l}1 \\
1.11 \\
5 \\
\end{array}$ & $\begin{array}{l}3 \\
5135.69 \\
3 \\
\end{array}$ & $\begin{array}{l}0 \\
0.00 \\
0 \\
\end{array}$ & $\begin{array}{l}5 \\
3.04 \\
9 \\
\end{array}$ \\
\hline \multicolumn{9}{|l|}{ Province } \\
\hline $\begin{array}{l}\text { Western } \\
\text { Cape ® }\end{array}$ & 1 & $\begin{array}{l}4925.97 \\
2\end{array}$ & $\begin{array}{l}0.00 \\
0\end{array}$ & 1 & 1 & $\begin{array}{l}6001.28 \\
7\end{array}$ & $\begin{array}{l}0.00 \\
0\end{array}$ & 1 \\
\hline
\end{tabular}


Structural Changes in the Participation of Migrants in the Labour Force

\begin{tabular}{|c|c|c|c|c|c|c|c|c|}
\hline $\begin{array}{l}\text { Eastern } \\
\text { Cape }\end{array}$ & $\begin{array}{l}- \\
0.05 \\
3\end{array}$ & 0.842 & $\begin{array}{l}0.35 \\
9\end{array}$ & $\begin{array}{l}0.94 \\
8\end{array}$ & $\begin{array}{l}0.33 \\
7\end{array}$ & 224.598 & $\begin{array}{l}0.00 \\
0\end{array}$ & $\begin{array}{l}1.40 \\
1\end{array}$ \\
\hline $\begin{array}{l}\text { Northern } \\
\text { Cape }\end{array}$ & $\begin{array}{l}0.36 \\
6\end{array}$ & 7.307 & $\begin{array}{l}0.00 \\
7\end{array}$ & $\begin{array}{l}1.44 \\
2\end{array}$ & $\begin{array}{l}0.61 \\
4\end{array}$ & 115.352 & $\begin{array}{l}0.00 \\
0\end{array}$ & $\begin{array}{l}1.84 \\
8\end{array}$ \\
\hline Free State & $\begin{array}{l}- \\
0.10 \\
6\end{array}$ & 7.806 & $\begin{array}{l}0.00 \\
5\end{array}$ & 0.89 & $\begin{array}{l}- \\
0.60 \\
9\end{array}$ & $\begin{array}{l}1166.99 \\
4\end{array}$ & $\begin{array}{l}0.00 \\
0\end{array}$ & $\begin{array}{l}0.54 \\
4\end{array}$ \\
\hline $\begin{array}{l}\text { KwaZulu- } \\
\text { Natal }\end{array}$ & $\begin{array}{l}- \\
0.03 \\
7\end{array}$ & 0.769 & $\begin{array}{l}0.38 \\
1\end{array}$ & $\begin{array}{l}0.96 \\
4\end{array}$ & $\begin{array}{l}0.12 \\
9\end{array}$ & 61.793 & $\begin{array}{l}0.00 \\
0\end{array}$ & $\begin{array}{l}1.13 \\
7\end{array}$ \\
\hline North West & $\begin{array}{l}- \\
0.05 \\
0\end{array}$ & 1.972 & $\begin{array}{l}0.16 \\
0\end{array}$ & $\begin{array}{l}0.95 \\
1\end{array}$ & $\begin{array}{l}- \\
0.13 \\
2\end{array}$ & 89.262 & $\begin{array}{l}0.00 \\
0\end{array}$ & $\begin{array}{l}0.87 \\
6\end{array}$ \\
\hline Gauteng & $\begin{array}{l}- \\
0.28 \\
5\end{array}$ & 74.182 & $\begin{array}{l}0.00 \\
0\end{array}$ & $\begin{array}{l}0.75 \\
2\end{array}$ & $\begin{array}{l}- \\
0.29 \\
5\end{array}$ & 801.349 & $\begin{array}{l}0.00 \\
0\end{array}$ & $\begin{array}{l}0.74 \\
4\end{array}$ \\
\hline $\begin{array}{l}\text { Mpumalan } \\
\text { ga }\end{array}$ & $\begin{array}{l}1.11 \\
6\end{array}$ & 804.729 & $\begin{array}{l}0.00 \\
0\end{array}$ & $\begin{array}{l}3.05 \\
3\end{array}$ & $\begin{array}{l}0.13 \\
2\end{array}$ & 71.604 & $\begin{array}{l}0.00 \\
0\end{array}$ & $\begin{array}{l}1.14 \\
1\end{array}$ \\
\hline Limpopo & $\begin{array}{l}0.59 \\
2\end{array}$ & 252.342 & $\begin{array}{l}0.00 \\
0\end{array}$ & $\begin{array}{l}1.80 \\
8\end{array}$ & $\begin{array}{l}0.23 \\
4\end{array}$ & 286.528 & $\begin{array}{l}0.00 \\
0\end{array}$ & $\begin{array}{l}1.26 \\
4\end{array}$ \\
\hline
\end{tabular}

Source: Own computation using StatsSA 2001 and 2011 census data. ${ }^{\circledR}=$ reference

As far as age is concerned, the probability of African migrants to be employed varied. African migrants aged 20-29 years were 1.154 times more likely to be employed than those who were 15-19 years old. Migrants who were 30-39 years were 2 times more likely to be employed. Furthermore, those who were in the ages 40-44 and 60-64 years were 3 times more likely to be employed than those who were 15-19 years. African migrants who were in the ages of 45-59 years were 4 times more likely to be employed compared to migrants who were 15-19 years old.

Marital status showed a significant relationship with the employment status. The results indicated that African migrants who were cohabiting 


\section{Yamkela Majikijela and Gabriel Tati}

$(\mathrm{OR}=0.700)$, never married $(\mathrm{OR}=0.563)$, widows $(\mathrm{OR}=0.788)$, separated $(\mathrm{OR}=0.591)$ and divorced $(\mathrm{OR}=0.879)$ were less likely to be employed than those African migrants who were married. Changes in marital status variables have been observed between the two periods.

Educational attainment indicated a very strong significant relationship with employment status. The likelihood of being employed among the African migrants increased with educational attainment, implying that African migrants who are more educated had a greater chance to find work in South Africa. African migrants who have completed primary education were 1.461 more likely to be employed that those who were not educated. Furthermore, African migrants with secondary school attainment were 1.647 time more likely to be employed than those who had no schooling. Finally, African migrants who had completed tertiary level of education were 3.489 more likely to be employed compared to African migrants who had no formal schooling.

The results for the province of enumeration indicated that there were variations between provinces for African migrants to be employed. African migrants who were enumerated in Free State $(\mathrm{OR}=0.899)$, Gauteng $(\mathrm{OR}=0.752)$ and KwaZulu-Natal $(\mathrm{OR}=0.964)$ were less likely to be employed compared to African migrants who were enumerated in the Western Cape. Furthermore, those whore were enumerated in Northern Cape (OR=1.442), Limpopo $(\mathrm{OR}=1.808)$ and Mpumalanga $(\mathrm{OR}=3.053)$ were more likely to be employed compared to those who were enumerated in Western Cape. However, those who were enumerated in Mpumalanga had a greater likelihood of being employed compared to those who were enumerated in Northern Cape and Mpumalanga.

The multivariate results for 2011 were reported in the last column of Table 7. The outcome of binary regression revealed a strong significant relationship between sex, age, marital status, educational attainment and province of enumeration. In 2011 the odds ratio $(\mathrm{OR}=0.338)$ of African female migrants to be employed was still less compared to African male migrants. Contrary to 2001 results, in 2011 the probability of African migrants to be employed increased with age. African migrants who were at age 20-24 years were 1.642 more likely to be employed than those at age 15-19 years. Migrants at age 25-34 years were 2 times more likely to be employed. Furthermore, African migrants who were at age 35-49 years were 3 times more likely to be employed than African migrants who were at age 15-19 years. Lastly, the probability of African migrants who were 50-64 years old was 4 times more 
likely to find employment compared to African migrants who were at age 1519 years old.

The 2011 results for marital status revealed that the likelihood to be employed among African migrants who were never married (OR=1.061), widows $(\mathrm{OR}=1.631)$, separated $(\mathrm{OR}=1.162)$ and divorced (2.864) increased and were likely to be employed compared to their married counterparts. However, the divorced were 2.864 more likely to be employed than African migrants who were married. Finally, those who were cohabiting $(0.770)$ were still less likely to find work compared to those that were married.

A similar trend was observed in educational attainment. African migrants who completed primary schooling were 1.212 more likely to be employed than African migrants who had no education. Whilst those who have completed secondary schooling were 1.585 more likely to be employed compared to those who did not go to school. To conclude, African migrants who completed tertiary level of education had a greater chance of being employed at 3.049 more compared to African migrants who had no formal schooling.

Results for the province of enumeration in 2011 revealed that there were variations between provinces for African migrants to be employed. Between the period of 2001 and 2011 there were some changes in the opportunity of African migrants to be employed within the provinces. African migrants enumerated in Free State $(\mathrm{OR}=0.544)$, North West $(0.876)$ and Gauteng (0.744) were less likely to be employed compared those who were enumerated in the Western Cape Province. However, those who were enumerated in Eastern Cape $(\mathrm{OR}=1.401)$, Northern Cape $(\mathrm{OR}=1.848)$, KwaZulu-Natal $(\mathrm{OR}=1.137)$, Mpumalanga $(\mathrm{OR}=1.141)$ and Limpopo $(\mathrm{OR}=1.264)$ were more likely to be employed than African migrants who were enumerated in Western Cape.

\section{Concluding Comments}

The results revealed that the number of African migrants who were part of the labour force increased within the ten-year period as shown in Table 1 with an average annual growth rate of $13.2 \%$. Inasmuch as there was an increase in the proportion of African migrants in the labour force over the period, the results further revealed that the proportion of males decreased while that of females 
increased. However, African male migrants still constitute a higher proportion. The increase in females may be due to feminisation of migration in Africa as women have started migrating more to seek employment opportunities and for other various reasons.

Through the analysis of the statistical data, it can be concluded that from 2001 to 2011 there has been changes in the participation of African migrants in the labour force of South Africa. It can be noted from the findings in the analysis that the participation of African male and female migrants differs across the different socioeconomic variables. Furthermore, there were gender inequalities between sexes in relation to education, employment and income. Despite the increasing rate of females over the period, the results revealed that African male migrants still form a bigger proportion of those in the labour force. Given the apartheid history in this country, this outcome is no surprise as African male migrants migrated to South Africa to work in mines in order to provide for their families.

Even though there was an increase in the number of African migrants who entered the South African labour force, there were fluctuations and incidents that took place within the period. The period was marked by economic, social and political events. The South African government continued to amend the immigration policy in order to control the migration flows. Despite all this, South Africa still managed to attract many migrants within this period $(2001-2011)$ as the number of African migrants increased in absolute numbers and in proportion.

\section{References}

Adepoju, A. 2004. Changing Configurations of Migration in Africa. Available at: http://www.migrationpolicy.org/article/changing-configurationsmigration-africa.

Bhorat, H., J. Meyer \& C. Mlatsheni 2002. Skilled Labour Migration from Developing Countries: Study on South and Southern Africa. International Labour Office: Geneva.

Bueker, C.S. 2004. The Personal is Political: The Relationship between Marital Status and Immigrant Political Incorporation. Electronic Journal of Sociology. ISSN: 1198 3655. Available at: http://www.sociology.org/con 
Structural Changes in the Participation of Migrants in the Labour Force

tent/2004/tier1/beuker.html (Accessed on 25 August 2015.)

Bustamante, J.A., G. Jasso, J.E. Taylor, \& P.T. Legarreta 1998. Characteristics of Migrants. The Selectivity of International Labour Migration and Characteristics of Mexico-to-U.S Migrants: Theoretical Considerations. In Migration between Mexico and the United States. Texas: Morgan Printing.

Crush, J. 2008. South Africa: Policy in the Face of Xenophobia. Migration Policy Institute.

Crush, J., S. Ramachandran \& W. Pendleton 2013. Soft Targets: Xenophobia, Public Violence and Changing Attitudes to Migrants in South Africa after May 2008. Migration Policy Series No. 64. Cape Town: Southern African Migration Programme.

Ghatak, S., P. Levine \& S.W. Price 1996. Migration Theories and Evidence: An Assessment. Journal of Economic Surveys 10,2: 159-197. Blackwell Publishers Ltd.

Industrial Development Corporation 2013. South African Economy: An Overview of Key Trends since 1994. Department of Research and Information.

International Labour Organization 2010. International Labour Migration. A

Right-based Approach. Geneva: International Labour Office.

Jolly, S. H. \& Reeves 2005. Gender and Migration. Overview Report. Institute of Development Studies.

Kanbur, R. \& H. Rapoport 2003. Migration Selectivity and the Evolution of Spatial Inequality. Cornell University.

Schachter, J.P. 2009. Data Assessment of Labour Migration Statistics in the SADC Region: South Africa, Zambia, Zimbabwe. International Organization for Migration.

United Nations. (2004). Women and International Migration. Department of Economic and Social Affairs. Available at: http://www.un.org/esa/ population/meetings/thirdcoord2004/P01_DAW.pdf. (Accessed on 10 October 2015.)

United Nations Population Division 2011. International Migration in a Globalizing World: The Role of Youth. United Nations: New York. Accessed at: http://www.un.org/esa/population/publications/technical papers/TP2011-1.pdf. (Accessed on 20 September 2015.) 
Yamkela Majikijela Department of Statistics and Population Studies University of the Western Cape ymajikijela@gmail.com

Gabriel Tati Department of Statistics and Population Studies University of the Western Cape gtati@uwc.ac.za 